\title{
DAMPAK PANDEMIC COVID 19 TERHADAP REAKSI PASAR PADA SEKTOR CONSUMER GOODS INDUSTRY DI BURSA EFEK INDONESIA
}

\author{
Ni Wayan Dian Irmayani ${ }^{1}$ \\ Politeknik Nasional Denpasar ${ }^{1}$ \\ Email: dianirmayani51@gmail.com ${ }^{1}$
}

\begin{abstract}
ABSTRAK
Penelitian ini bertujuan untuk meneliti Dampak Pandemic COVID-19 sebagai bencana darurat nasional terhadap return pada saham sub sektor Consumer Good Industry di Bursa Efek Indonesia yang dilihat dari perbedaan average abnormal return saham sebelum dan sesudah Pandemic COVID-19 ditetapkan sebagai bencana darurat nasional pada tanggal 2 Maret 2020.

Populasi dalam penelitian ini adalah perusahaan sub sektor Consumer Good Industry di Bursa Efek Indonesia dengan jumlah 44 perusahaan sub sektor Consumer Good Industry. Dengan menggunakan metode census sampling meliputi keseluruhan populasi. Penelitian difokuskan pada periode jendela, yaitu 10 hari sebelum dan 10 hari sesudah tanggal peristiwa. Data dianalisis dengan menggunakan uji paired sample t-test.

Dari penelitian yang dilakukan diketahui bahwa tidak terdapat perbedaan sebelum dan sesudah Pandemic COVID-19 ditetapkan sebagai bencana darurat nasional terhadap return saham perusahaan sub sektor Consumer Good Industry di Bursa Efek Indonesia. Hal ini dapat diketahui dari adanya penurunan average abnormal return pada periode jendela sesudah ditetapkannya Pandemic COVID-19 sebagai bencana darurat nasional. Adapun nilai average abnormal return periode jendela sebelum peristiwa adalah 0,00949 dan periode jendala sesudah adalah peristiwa $-0,00252$.
\end{abstract}

Kata Kunci : Pasar Modal; Event Study; Abnormal Return; Pandemic COVID-19.

\section{ABSTRACT}

This study aims to examine the impact of the COVID-19 pandemic as a national emergency on returns on the shares of the Consumer Good Industry sub-sector on the Indonesia Stock Exchange as seen from the difference in the average abnormal return of stocks before and after the Covid Pandemic 19 was designated as a national emergency on the 2nd. March 2020.

The population in this study is the Consumer Good Industry sub-sector companies in the Indonesia Stock Exchange with a total of 44 companies in the Consumer Good Industry sub-sector. By using the census sampling method covering the entire population. The study focused on the window period, which is 10 days before and 10 days after the event date. Data were analyzed using paired sample t-test.

From the research conducted, it is known that there is no difference before and after the COVID-19 Pandemic was declared a national emergency disaster on the stock returns of the Consumer Good Industry sub-sector on the Indonesia Stock Exchange. This can be seen from the decrease in the average abnormal return in the window period after the Covid Pandemic 19 was declared a national emergency. The average abnormal return value for the window period before the event is 0,00949 and the window period after is $-0,00252$.

Keywords: Pasar Modal; Event Study; Abnormal Return; Pandemic COVID-19. 


\section{PENDAHULUAN}

Pasar modal adalah pasar yang mempertemukan investor yang memiliki kelebihan dana dengan investor yang membutuhkan dana dengan cara mentransaksikan sekuritas (Tandelilin, 2010). Sumber dana yang diperoleh berasal dari sumber dana intern dan sumber dana ekstern. Sumber dana intern yaitu sumber dana yang diperoleh dari perusahaan itu sendiri sedangkan sumber dana ekstern yaitu sumber dana yang diperoleh dari luar perusahaan. Pasar modal menjadi sarana bagi masyarakat untuk berinvestasi pada instrumen keuangan seperti obligasi, saham, reksadana, dan lain sebagainya sehingga hal ini akan membuat peranan pasar modal terhadap perekonomian suatu negara semakin penting. Pasar modal yang memiliki pengaruh besar terhadap perekonomian negara memiliki gejolak naikturun karena bersifat sensitif akan perubahan terhadap hal hal yang mempengaruhinya.

Pasar modal dipengaruhi oleh peristiwa-peristiwa yang ada pada suatu negara. Peristiwa yang memiliki kandungan informasi dapat menyebabkan pasar bereaksi saat menerima informasi dari peristiwa tersebut. Peristiwa yang terjadi dapat mengandung informasi yang diserap oleh pasar dan akan digunakan oleh para investor untuk dasar pengambilan strategi atau keputusan investasi. Peristiwa yang terjadi juga dapat mempengaruhi reaksi pasar jika informasi yang didapatkan adalah informasi yang relevan sehingga dapat mempengaruhi pengambilan keputusan oleh investor untuk memperoleh keuntungan maksimal. Investor dalam pengambilan strategi investasinya dituntut untuk mengetahui peristiwa-peristiwa penting baik ekonomi maupun non ekonomi yang meliputi peristiwa politik, sosial, budaya, dan yang dapat mengganggu stabilitas nasional seperti tanah longsor, gunung meletus hingga penyebaran virus COVID-19 yang sedang terjadi di 
negara negara di seluruh dunia (okefinance news). Indonesia sebagai salah satu negara yang terdampak virus COVID-19 yang membuat aparatur negara untuk menghimbau masyarakat untuk melakukan physical distancing, bekerja, belajar, dan beribadah di rumah, hingga larangan untuk berkurumun untuk menghindari virus agar tidak semakin menyebar (cnbc.com).

Pandemi Covid-19 berdampak pada perekonomian Indonesia. Berbagai sektor industri terkena dampak tersebut, seperti sektor keuangan,sektor pariwisata, sektor manufaktur, sektor food and beverage. Adapun sektor finansial sudah terkena dampaknya jauh sebelum COVID-19 menyerang Indonesia. Aksi jual di bursa saham dan pasar obligasi terjadi sejak bulan Februari, dan semakin masif di bulan Maret ketika kasus pertama Covid diumukan di Indonesia dan ditambah dana asing masih pergi dari pasar Indonesia (Kartikaningsih, 2020). Hasil penelitian Baumöhl et al. (2020) menunjukkan bahwa risiko sistemik di antara bank-bank di seluruh dunia sangat tinggi terjadi selama pandemi COVID-19.

Berkembangnya virus COVID-19 merupakan informasi eksternal yang secara tidak langsung dapat berdampak pada pembelian saham khususnya di Bursa Efek Indonesia khusunya pada Perusahaan Sektor Consumer Good Industry. Peristiwa COVID-19 meningkatkan volatilitas pasar saham sesuai dengan hasil penelitian Sharif et al. (2020), Zaremba dkk. (2020) dan Zhang et al. (2020).Perusahaan Sektor Consumer Good Industry memiliki pertumbuhan dan nilai transaksi yang tinggi, namun dengan adanya pandemic COVID-19 ini berimbas pada pembelian Sektor Consumer Good Industry yang ikut menurun seperti contoh semester I-2019 ke semester I-2020 saham KINO mencatatkan 
penurunan pendapatan komprehensif yang cukup signnifikan yaitu sebesar $65,8 \%$ (Sari, 2020). Untuk membuktikan peristiwa tersebut memberikan dampak terhadap pasar modal Indonesia maka akan dilakukan pengujian terhadap kandungan informasi peristiwa tersebut dengan menggunakan event study (studi peristiwa). Reaksi pasar modal terhadap suatu peristiwa terdapat kandungan informasi dapat diukur dengan menggunakan return atau dengan menggunakan abnormal return (Jogiyanto, 2003).

Return merupakan hasil yang diperoleh dari investasi di pasar modal. Return dapat dibagi menjadi return realisasi dan return ekspektasi. Jogiyanto (2005), mendefinisikan return realisasi sebagai return yang telah terjadi yang dapat dihitung berdasarkan data historis. Sedangkan return ekspektasi adalah return yang diharapkan akan diperoleh oleh investor di masa mendatang. Berbeda dengan return realisasi, return ekspektasi sifatnya belum terjadi dan menggunakan return realisasi sebagai dasar mengukur return ekspektasi.

Abnormal return merupakan selisih antara return realisasi (actual return) dan return ekspektasi (expected return). Selisih dari kedua return dapat berupa selisih positif dan selisih negatif. Jika abnormal return positif maka actual return atau return yang sesungguhnya lebih besar dari return yang diharapkan oleh investor, begitu sebaliknya jika abnormal return bernilai negatif. Peningkatan transaksi yang tidak normal atau tidak wajar di sekitar periode pengumuman pemecahan saham menyebabkan terjadinya abnormal return.

Hal tersebut mendorong ketertarikan untuk melakukan penelitian dengan judul “ Dampak Pandemic COVID-19 Terhadap Reaksi Pasar Modal pada Sektor Consumer Good Industry di Bursa Efek Indonesia”. Pentingnya penelitian ini diadakan adalah untuk mengukur kesempatan adanya abnormal return yang dapat dimanfaatkan oleh investor selama studi 
peristiwa yang sedang terjadi ini terutama pada Sektor Consumer Good Industry .

Studi Peristiwa (event study) merupakan metodologi yang ditemukan oleh Eugene Fama pada tahun 1969 yang tujuannya mengamati reaksi pasar terhadap suatu peristiwa (event) yang informasinya dipublikasikan sebagai suatu pengumuman. Event study berguna untuk menguji kandungan informasi dari suatu pengumuman, di samping itu juga berguna untuk menguji efisiensi pasar bentuk setengah kuat. Penelitian yang menggunakan event study berkaitan dengan seberapa cepat informasi masuk ke pasar dan mempengaruhi harga sekuritas.

Pasar dikatakan efisien bentuk setengah kuat jika tidak terdapat abnormal return pada saat pengumuman, akan tetapi jika terdapat abnormal return pasar masih bisa dikatakan efisien bentuk setengah kuat dengan kondisi pasar harus cepat bereaksi dan menuju harga keseimbangan yang baru (Surya Negara, 2006). Dapat disimpulkan bahwa pengujian efisiensi pasar setengah kuat dapat dilakukan setelah pengujian kandungan informasi.

Maka dapat dirumuskan hipotesis hipotesis sebagai berikut:

H1: Terdapat perbedaan rata-rata abnormal return yang signifikan pada perusahaan sub Sektor Consumer Good Industry di Bursa Efek Indonesia.

\section{METODE PENELITIAN}

Jenis penelitian ini merupakan penelitian yang berjenis studi peristiwa atau event study. Studi peristiwa merupakan suatu metode yang dapat mengukur dampak dari sebuah peristiwa. Penelitian ini dilakukan di Bursa Efek Indonesia. Data di akses melalui web

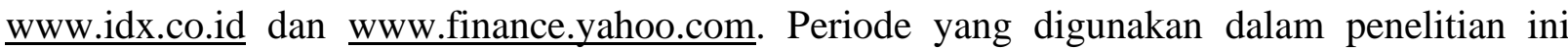
adalah selama 21 hari bursa yaitu periode kejadian (event period). Ditinjau dari rumusan 
masalah dan hipotesis yang telah diuraikan, maka variabel yang akan dianalisis dalam penelitian ini adalah abnormal return. Variabel ini akan diamati selama periode jendela yaitu 21 hari termasuk hari $\mathrm{h}$ peristiwa. Hasil pengamatan selama 21 hari nanti akan didokumentasikan dan dilakukan pengujian atas reaksi pasar yang terjadi. Reaksi pasar dapat diketahui melalui keberadaan abnormal return di sepanjang periode peristiwa,

Besarnya expected return saham diukur menggunakan market model. Model ini memberikan kemudahan dalam melakukan pendeteksian abnormal return dibanding model lainnya. Model ini menggunakan alpha dan bheta dalam menghitung expected return. Alpha dan bheta diperoleh dengan cara meregresikan return pasar harian dengan actual return, perhitungan ini sebelumnya digunakan juga oleh Ayu Mila (2010) :

$$
A R_{i t}=R_{i t}-E\left[R_{i t}\right]
$$

Notasi:

$$
\begin{array}{ll}
\mathrm{Y} & =\text { Return saham harian yang sesungguhnya atau } \mathrm{R}_{i t .} . \\
\mathrm{X} & =\text { Return pasar }(\mathrm{Rmt}) \\
\mathrm{n} & =\text { Periode Pengamatan }
\end{array}
$$

Market model memiliki potensi untuk menghasilkan tes statistik yang kuat dibanding model statistik yang dihasilkan model lainnya yaitu mean adjusted dan market adjusted model (Jogiyanto, 2010). Setelah mendapatkan alpha dan bheta, model statistik yang digunakan menghitung berupa regresi atau OLS (Ordinary Least Squares) sebagai berikut:

$$
\mathrm{Rij}=\alpha \mathrm{i}+\beta \mathrm{i} \mathrm{R} \mathrm{Mj}+\mathrm{Eij} .
$$

Notasi :

$$
\begin{array}{ll}
\mathrm{Rij} & =\text { Return realisasi sekuritas ke-i pada periode estimasi ke-j. } \\
\alpha \mathrm{i} & =\text { Intercept untuk sekuritas ke-i. } \\
\beta \mathrm{i} & =\text { Koefisien slope yang merupakan beta sekuritas ke-i. } \\
\mathrm{RMj} & =\text { Return indeks pasar pada periode estimasi ke-j. } \\
\mathrm{Eij} & =\text { Kesalahan residu ke-i pada periode estimasi ke-j. } \\
\mathrm{IHSG}_{\mathrm{t}-1} & =\text { Indeks Harga Saham Gabungan hari ke-t-1 }
\end{array}
$$


Penelitian ini menggunakan event study untuk mengamati pergerakan abnormal return dari hari ke hari dengan periode jendela 21 hari. Alasan dipilihnya 21 hari periode kejadian untuk menghindari confounding effects, dimana confounding effects yaitu untuk menghindari dampak tercampurnya suatu peristiwa yang diamati dengan peristiwa yang lainnya hal ini juga mengacu pada periode berdasarkan pendapat jogiyanto (2003:435). Periode kejadian selama 21 hari, yakni terdiri dari 10 hari sebelum peristiwa (preevent), 1 hari pada saat peristiwa (event date) dan 10 hari sesudah peristiwa (post event).

Pada tanggal 2 Maret 2020 Presiden Joko Widodo untuk pertama kalinya mengumumkan dua pasien positif virus corona, dua pasien itu adalah ibu dan anak yang diduga tertular dari warga negara Jepang (Nugroho, 2020). Terjadinya Pandemic COVID-19 pada tanggal 2 Maret 2020 merupakan hari disaat peristiwa terjadi atau event date (Sekaran, 2017).

Populasi yang digunakan dalam penelitian ini adalah perusahaan yang terdaftar pada Sektor Consumer Good Industry di Bursa Efek Indonesia. Sumber data penelitian ini diperoleh dari data sekunder yakni data penelitian diperoleh secara tidak langsung. Data sekunder (Secondary data) merupakan data yang mengacu pada informasi sumber-sumber yang telah ada yaitu seperti catatan atau dokumentasi perusahaan, publikasi pemerintah, website, internet dan lain. sebagainya (Sekaran, 2017). Data dari penelitian ini bersumber pada website resmi BEI (Bursa Efek Indonesia) dan laporan-laporan tahunan perusahaan Sektor Consumer Good Industry. Metode pengumpulan data yang digunakan dalam penelitian ini adalah metode dokumentasi dengan cara mengambil secara langsung sumber data yang tersedia. Penelitian ini melakukan beberapa uji hipotesis, sebelum melakukan pengujian hipotesis, dilakukan uji normalitas terlebih dahulu data yang di uji adalah data average abnormal return (AAR) 
sebelum dan sesudah peristiwa. Uji kenormalan dilakukan dengan menggunakan alat statistik SPSS yaitu uji one-sample kolmogorovsmirnov test. Apabila data berdistribusi normal pengujian hipotesis menggunakan uji statistik parametrik yaitu paired sample t-test (uji t).

\section{HASIL DAN PEMBAHASAN}

Dari keseluruhan 44 perusahaan sub Sektor Consumer Good Industry di Bursa Efek Indonesia, Dilihat dari average abnormal return sebelum dan sesudah peristiwa Pandemic COVID-19 ditetapkan oleh Pemerintah sebagai bencana nasional, hanya ada 6 perusahaan sub Sektor Consumer Good Industry yang memiliki average abnormal return lebih besar dari sesudah ditetapkan Pandemic COVID-19 sebagai bencana nasional yaitu PT Budi Starch \& Sweetener Tbk., PT Wilmar Cahaya Indonesia Tbk., PT Kino Indonesia Tbk., PT Mustika Ratu Tbk., PT Prima Cakrawala Abadi Tbk. dan PT Pyridam Farma Tbk. Hal ini berarti terjadi respon pasar yang positif setelah peristiwa Pandemic COVID-19 ditetapkan oleh Pemerintah sebagai bencana nasional pada 6 perusahaan sub Sektor Consumer Good Industry. Hal ini disebabkan 6 perusahaan sub Sektor Consumer Good Industry merupakan perusahaan konsumsi industri makanan, minuman, obat-obatan (farmacy) dan minuman kesehatan yang paling diminati dan dibutuhkan oleh pasar pada kondisi Pandemic COVID-19 saat ini.

Tabel 1.

Hasil uji paired samplet-test

\begin{tabular}{|c|c|c|c|c|c|c|c|c|c|}
\hline \multicolumn{10}{|c|}{ Paired Samples Test } \\
\hline & \multicolumn{9}{|c|}{ Paired Differences } \\
\hline & & \multirow[b]{2}{*}{ Mean } & \multirow[b]{2}{*}{ Std. Deviation } & \multirow{2}{*}{$\begin{array}{l}\text { Std. Error } \\
\text { Mean }\end{array}$} & \multicolumn{2}{|c|}{$\begin{array}{c}\text { 95\% Confidence Interval of the } \\
\text { Difference }\end{array}$} & \multirow[b]{2}{*}{$t$} & \multirow[b]{2}{*}{$d f$} & \multirow[b]{2}{*}{ Sig. (2-tailed } \\
\hline & & & & & Lower & Upper & & & \\
\hline Pair 1 & SEBELUM - SESUDAH & .012012 & .031633 & .010003 & .010617 & .034640 & 1.201 & 9 & .260 \\
\hline
\end{tabular}


Sumber : Data diolah, 2020.

Berdasarkan hasil pengolahan data menggunakan SPSS 24.0 secara keseluruhan 44 perusahaan sub Sektor Consumer Good Industry di Bursa Efek Indonesia, diketahui bahwa Sig. adalah 0,260 yang berarti bahwa 0,260 > 0,05, maka H0 diterima dan H1 ditolak yang berarti tidak terdapat perbedaan average abnormal return yang signifikan sebelum dan sesudah peristiwa Pandemic COVID-19 ditetapkan sebagai bencana nasional pada tanggal 2 Maret 2020. Hal tersebut berarti investor tidak berpeluang untuk mendapatkan return tinggi yang tidak biasa saat berinvestasi saham di perusahaan sub Sektor Consumer Good Industry di Bursa Efek Indonesia dengan memanfaatkan peristiwa Pandemic COVID-19.

Hasil uji paired samplet-test menunjukkan tidak terdapat perbedaan reaksi pasar sebelum dan sesudah peristiwa Pandemic COVID-19 ditetapkan sebagai bencana nasional terhadap saham-saham sektor Consumer Good Industry di Bursa Efek Indonesia sehingga hal tersebut berarti sikap investor dalam berinvestasi saham tetap sama baik sebelum maupun setelah peristiwa Pandemic COVID-19. Investor dalam 10 hari setelah diumumkan kasus COVID-19 pertama di Indonesia, tidak terlalu berpengaruh dalam kegiatan transaksi sahamnya jika dibandingkan dengan 10 hari sebelum diumumkannya. Dalam jangka 10 hari tersebut investor tidak terlalu memperdulikan informasi mengenai COVID-19 tersebut.

Tabel 1.

Hasil uji paired samplet-test

Paired Samples Statistics

\begin{tabular}{llc|r|r|r} 
& & & & \multicolumn{1}{c}{$\begin{array}{c}\text { Std. Error } \\
\text { Mean }\end{array}$} \\
\hline Pair 1 & SEBELUM & .00949 & 10 & .013292 & .004203 \\
\cline { 2 - 6 } & SESUDAH & -.00252 & 10 & .022492 & .007113 \\
\hline
\end{tabular}


Sumber: Data diolah, 2020.

Average abnormal return sesudah Pandemic COVID-19 lebih kecil dibandingkan sebelum Pandemic COVID-19. Dibuktikan dari hasil signifikansi average abnormal return sebelum peristiwa adalah 0,00949 dan sesudah peristiwa $-0,00252$. Hal tersebut berarti investor sebelum peristiwa COVID-19 dapat menikmati rata-rata abnormal return sebesar $0.95 \%$, sedangkan sesudah peristiwa investor tidak dapat menikmati abnormal return dan justru mengalami defisit rata-rata sebesar $0.25 \%$ yang artinya investor akan merugi jika bertransaksi saham setelah peristiwa COVID-19. Hasil ini sesuai dengan hasil penelitian Ashraf (2020) yang menemukan bahwa pasar saham merespons secara negatif terhadap pertumbuhan kasus COVID-19. Hasil penelitian menemukan respon pasar yang negatif setelah peristiwa Pandemic COVID-19 pada sub Sektor Consumer Good Industry. Pasar modal Indonesia akan bereaksi pada peristiwa Pandemic COVID-19 sebagai bencana darurat nasional sebagai sebuah informasi penting yang mampu mempengaruhi harga saham perusahaan sub Sektor Consumer Good Industry di Bursa Efek Indonesia secara keseluruhan. Refleksi kepercayaan terhadap perusahaan saat terjadinya Pandemic COVID19 semakin menurun, dalam hal ini investor tidak mendapatkan keuntungan diatas normal. Selain itu tidak ada satu atau beberapa pelaku pasar dapat menikmati adanya reaksi pasar. Hasil ini mendukung pasar efisien setengah kuat yang berarti kondisi pasar cepat bereaksi atas informasi yang diberikan oleh publik terkait virus Pandemic COVID-19.

\section{SIMPULAN DAN SARAN}

Penelitian menggunakan event study peristiwa Pandemic COVID-19 sebagai 
bencana darurat nasional pada tanggal 2 Maret 2020. Perusahaan yang menjadi obyek penelitian sebanyak 44 perusahaan sub Sektor Consumer Good Industry di Bursa Efek Indonesia. Berdasarkan analisis dan pembahasan yang telah dilakukan, dapat diambil kesimpulan sebagai berikut:

Dari 44 Perusahaaan sub Sektor Consumer Good Industry hanya ada 6 perusahaan sub Sektor Consumer Good Industry yang memiliki average abnormal return lebih besar dari sesudah Pandemic COVID-19 yaitu PT Budi Starch \& Sweetener Tbk., PT Wilmar Cahaya Indonesia Tbk., PT Kino Indonesia Tbk., PT Mustika Ratu Tbk., PT Prima Cakrawala Abadi Tbk. dan PT Pyridam Farma Tbk. Hal ini berarti terjadi respon pasar yang positif setelah peristiwa Pandemic COVID-19 pada 6 perusahaan sub Sektor Consumer Good Industry. Tetapi secara keseluruhan dari 44 perusahaan sub Sektor Consumer Good Industry di Bursa Efek Indonesia. Hasil uji paired samplet-test menunjukkan tidak terdapat perbedaan reaksi pasar sebelum dan sesudah peristiwa Pandemic COVID-19. Hal ini menunjukkan secara keseluruhan bahwa tidak terdapat reaksi pasar sebelum dan sesudah Pandemic COVID-19. Average abnormal return sesudah Pandemic COVID-19 lebih kecil dibandingkan sebelum peristiwa Pandemic COVID-19 ditetapkan sebagai bencana nasional. Dibuktikan dari hasil signifikansi average abnormal return sebelum peristiwa adalah 0,00949 dan sesudah peristiwa -0,00252. Hasil terjadi respon pasar yang negatif setelah peristiwa Pandemic COVID-19 pada sub Sektor Consumer Good Industry. Refleksi kepercayaan terhadap perusahaan saat terjadinya Pandemic COVID-19 semakin menurun, Dalam hal ini investor tidak mendapatkan keuntungan diatas normal.

Penelitian ini diharapkan dapat bermanfaat bagi investor, bagi perusahaan, dan bagi 
penelitian-penelitian selanjutnya. Berdasarkan simpulan yang ada, kepada investor disarankan untuk menganalisa setiap informasi sebelum berinvestasi di pasar modal, Bursa Efek Indonesia (BEI) hendaknya memberikan informasi yang lebih transparan dan cepat kepada masyarakat. Hal ini dimaksudkan agar masyarakat pelaku pasar modal lebih cepat menyesuaikan atau mengantisipasi informasi tersebut dalam transaksi sekuritas. Informasi tersebut nantinya akan tercermin pada harga saham. Pemerintah diharapkan selalu dapat memberikan suasana kondusif dengan menerbitkan kebijakan-kebijakan yang mampu menunjang perkembangan pasar modal Indonesia seperti pemberian insentif pajak, pembebasan tarif, dan penyesuaian aturan kepada produsen dengan harapan harga-harga barang dan jasa masih dapat dijangkau daya beli masyarakat. Penelitian ini menggunakan periode penelitian selama 21 hari yang tepat untuk jenis investasi saham jangka pendek. Bagi Penelitian selanjutnya diharapkan dapat memperpanjang periode pengamatan seperti dua tahun dengan satu tahun sebelum dan sesudah untuk ditujukan kepada jenis investasi jangka panjang, dengan periode pengamatan yang lebih panjang, dapat dilihat dengan lebih jelas bagaimana reaksi pasar setelah peristiwa Pandemic COVID-19 ditetapkan sebagai bencana nasional serta diharapkan dapat menggunakan metode perhitungan abnormal return lainnya seperti CAPM, Mean adjuted model, atau Market adjusted model sebagai bahan pembanding.

\section{REFERENSI}

Anto Dajan. 2004. Pengantar Metode Statistik Jilid II, cetakan 18, Pustaka LP3ES, Jakarta. Ashraf,B.N. 2020. Stock markets' reaction to COVID-19: cases or fatalities? Res. Int. Bus. Finance, p. 101249

Baumöhl, E., Bouri, E., Hoang, T.-H.-V., Shahzad, S. J. H., Výrost, T., 2020. From physical 
to financial contagion: the COVID-19 pandemic and increasing systemic risk among banks. EconStor Working Paper no. 218944. ZBW Leibniz Information Centre for Economics. http://hdl.handle.net/10419/218944.

Fama, E.F. 1970. Efficient Capital Markets: A Review Of Theory and Empirical Work. Journal of Finance. 2(3). 383-417.

Jogiyanto H.,M. 2003. Pasar Efisien Secara Keputusan. Edisi pertama. Jakarta: PT Gramedia Pustaka Utama.

Jogiyanto H.,M. 2005. Pasar Efisien Secara Keputusan. Edisi pertama. Jakarta: PT Gramedia Pustaka Utama.

Jogiyanto H.,M. 2010. Teori Portofolio dan Analisis Investasi. Edisi Ketujuh. Yogyakarta: BPFE-Yogyakarta.

K., Awan Wahyu. 2011. IDX. The Indonesia Stock Market. [Online] 03062011. https://www.idx.co.id/media/1482/lq45-index-methodology-by-idx.pdf.

Kartikaningsih, Dewi. 2020. "Pengaruh Nilai Tukar terhadap Harga Saham Perusahaan Sektor Food and Beverage Di Masa Pandemi Covid-19." (BISMA: Jurnal Bisnis dan Manajemen) 14(2). .1-20

Mila W., I Gusti Ayu. 2010. Analisis Pengaruh Pemecahan Saham (Stock Split) Terhadap Volume Perdagangan Saham Dan Abnormal Return Saham Pada Perusahaan Yang Terdaftar Di Bei Tahun 2007 - 2009. Skripsi. Universitas Diponegoro, Semarang.

Nugroho, Rizal Setyo. Rekap Kasus Corona Indonesia Selama Maret dan Prediksi di Bulan April. 31032020.

Oke Finance. [Online] [Cited: 0110 2020.] https://www.okefinance.com/.

Pradnyana, Andika dan Widanaputra.2013.Dampak Pengumuman Pemecahan Saham Pada Perbedaan Abnormal return.Jurnal Akuntansi Universitas Udayana.

Pransuamitra, Putu Agus. 2020. CNBC Indonesia. Tanpa Tanding! Melesat 9\% Rupiah Libas $\begin{array}{lllllll}\text { Mata Uang Asia \& } & \text { Eropa. } \quad \text { [Cited: } & 01 & 10 & 2020 .]\end{array}$ https://www.cnbcindonesia.com/market/20200502083900-17-155779/tanpatanding-melesat-9-rupiah-libas-mata-uang-asia-eropa/1.

Sari, Fitriana Monica. 2020. Riset: Hanya Satu Emiten Personal Care yang Miliki Performa https://www.validnews.id/Riset--Hanya-Satu-Emiten-Personal-Care-yang-MilikiPerforma-Baik-QWA (accessed 10 01, 2020). 
Sekaran, Uma. 2017. Metode Penelitian untuk Bisnis. Jakarta: Salemba Empat.

Sharif, C. Aloui, L. YarovayaCOVID-19 Pandemic, oil prices, stock market, geopolitical risk and policy uncertainty nexus in the US economy: fresh evidence from the waveletbased approach Int. Rev. Financ. Analy. (2020), p. 101496

Suad, Husnan. 2009. Dasar-Dasar Teori Portofolio Dan Analisis Sekuritas Edisi Kelima. Yogyakarta: UPP AMP YKPN.

Sugianto, Danang. 2020. detikFinance. Begini Virus Corona Lumpuhkan Ekonomi RI. [Online] 2903 2020. [Cited: 0110 2020.] https://finance.detik.com/beritaekonomibisnis/d-4957376/beginivirus-corona-lumpuhkan-ekonomiri/2\#.

Sugiyono, 2011. Metode Penelitian Bisinis Pendekatan Kualitatif dan Kuantitatif, R\&D, Alfabeta, Badung.

Sugiyono. 2009. Metode Penelitian Bisnis. Bandung: CV Alfabeta.

Surya Negara, I Made. 2006. Dampak Kenaikan The Federal Fund Rate dan BI Rate Terhadap Reaksi Pasar Saham-Saham LQ-45 di Bursa Efek Jakarta Tahun 2005. Tesis tidak diterbitkan. Denpasar: Universitas Udayana.

Tandelilin, Eduardus. 2010. Portofolio dan Investasi: Teori dan Aplikasi. Edisi Pertama. Yogyakarta: Kanisius.

Zaremba, R. Kizys, D.Y. Aharon, E. 2020. DemirInfected markets: novel coronavirus, government interventions, and stock return volatility around the globe Finance Res. Lett., p. 101597

Zhang, M. Hu, Q. JiFinancial markets under the global pandemic of COVID-19 Finance Res. Lett. (2020), p. 101528 